\title{
Correction to: Impacts of Coastal Land Use and Shoreline Armoring on Estuarine Ecosystems: an Introduction to a Special Issue
}

\author{
Diann J. Prosser ${ }^{1}$ (D) Thomas E. Jordan ${ }^{2} \cdot$ Jessica L. Nagel ${ }^{1} \cdot$ Rochelle D. Seitz $^{3} \cdot$ Donald E. Weller $^{2} \cdot$ Dennis F. Whigham $^{2}$
}

Published online: 22 January 2019

(C) The Author(s) 2019

\section{Correction to: Estuaries and Coasts (2018) 41 (Suppl 1):S2- S18 https://doi.org/10.1007/s12237-017-0331-1}

The article Impacts of Coastal Land Use and Shoreline Armoring on Estuarine Ecosystems: an Introduction to a Special Issue, written by Diann J. Prosser, Thomas E. Jordan, Jessica L. Nagel, Rochelle D. Seitz, Donald E. Weller, and Dennis F. Whigham was originally published electronically on the publisher's internet portal (currently SpringerLink) on 18 December 2017 without open access.

With the author(s)' decision to opt for Open Choice the copyright of the article changed January 2019 to $($ C The Author(s) 2019 and the article is forthwith distributed under the terms of the Creative Commons Attribution 4.0 International License (http://creativecommons.org/licenses/by/4.0/), which permits use, duplication, adaptation, distribution and reproduction in any medium or format, as long as you give appropriate credit to the original author(s) and the source, provide a link to the Creative Commons license and indicate if changes were made.

The original article has been corrected.

Open Access This article is distributed under the terms of the Creative Commons Attribution 4.0 International License (http://creativecommons.org/licenses/by/4.0/), which permits unrestricted use, distribution, and reproduction in any medium, provided you give appropriate credit to the original author(s) and the source, provide a link to the Creative Commons license, and indicate if changes were made.

The online version of the original article can be found at https://doi.org/ 10.1007/s12237-017-0331-1

Diann J. Prosser

dprosser@usgs.gov

1 Patuxent Wildlife Research Center, Beltsville Laboratory, U.S. Geological Survey, 10300 Baltimore Avenue, Beltsville, MD 20705, USA

2 Smithsonian Environmental Research Center, 647 Contees Wharf Road, Edgewater, MD 21037, USA

3 Virginia Institute of Marine Science, College of William \& Mary, PO Box 1346, Gloucester Point, VA 23062, USA 